\title{
Gigantic Calculi in Continent Urinary Diversion
}

\author{
Kontinan Üriner Diversiyonunda Devasa Taşlar
}

\author{
(D) Siddalingeshwar Neeli, (1) Sree Harsha Nutalpati, (1) Manas Sharma \\ Jawaharlal Nehru Medical College and KLES Dr Prabhakar Kore Hospital and MRC, Department of Urology, Belagavi, India
}

\begin{abstract}
Continent urinary reservoirs are safe and accepted modes of urinary diversion in selected patients. However, they are associated with long-term complications such as recurrent pyelonephritis, metabolic acidosis, urolithiasis and stomal problems. We are reporting a patient who had undergone continent urinary diversion for the treatment of extrophy of the bladder and presented ten years later with formation of large pouch calculi and infection. The calculi were successfully retrieved by pouchotomy. The combined weight of the stones was 1,254 gms. To the best of our knowledge, this is the largest stone burden in continent urinary diversion reported in literature.
\end{abstract}

Keywords: Pouch calculus, Urinary diversion, Urolithiasis, Poucholithotomy

$\ddot{0} z$

Kontinan üriner rezervuarlar, seçilmiş hastalarda güvenli ve kabul edilen üriner diversiyon modlarıdır. Bununla birlikte, tekrarlayan piyelonefrit, metabolik asidoz, ürolitiyazis ve stomal problemler gibi uzun vadeli komplikasyonlarla ilişkilidirler. Bu yazıda, mesane ekstrofisi tedavisi için kontinan üriner diversiyon operasyonu uygulanan ve on yıl sonra büyük poş taşları oluşumu ve enfeksiyon ile başvuran bir hastayı bildiriyoruz. Taşlar, cerrahi ile başarılı bir şekilde alındı. Taşların toplam ağırlığı 1.254 gramdı. Bildiğimiz kadarıyla bu, literatürde bildirilen kontinan üriner diversiyondaki en büyük taş yüküdür.

Anahtar Kelimeler: Poş taşı, Üriner diversiyon, Ürolitiyazis, Litotomi ile poş cerrahisi

\section{Introduction}

Urinary diversion is indicated when the bladder can no longer be a functional and safe reservoir for the storage of urine. It is commonly done in conditions such as bladder cancer, neurogenic bladder due to congenital or traumatic etiology, radiation injury to the bladder, intractable urinary incontinence in females, and chronic pelvic pain syndrome (1). The primary means of urinary diversion after refinement in surgical techniques over the years is the continent cutaneous diversion. This is achieved by using an intestinal segment to provide a reservoir that is catheterizable by the patients. Patients undergoing this procedure perceive themselves as having a superior body image and an improved quality of life as compared to non-continent diversion procedures (1). Urinary lithiasis of both upper and reconstructed lower urinary tracts are included among the numerous technical and metabolic complications associated with urinary diversion. The incidence of this complication reported in the literature ranges from 2 to 52\% (2-6) with calculus size averaging $3 \mathrm{~cm}$ (7). Pouch calculi can be asymptomatic or present with varying clinical features. Endoscopic or percutaneous interventions in small-sized calculi to open approach in large calculi are some of the management strategies (8). We present a case of large pouch calculi in a continent urinary diversion case and its successful management through an open surgical approach.

\section{Case Presentation}

A 17-year-old man was referred to our center in 2008 with a diagnosis of exstrophy-epispadias complex, squamous metaplasia of the bladder plate with bilateral hydroureteronephrosis, and raised serum creatinine levels $(1.8 \mathrm{mg} / \mathrm{dL})$. He was managed with bladder plate excision and cutaneous continent urinary diversion (double T-pouch) with flap coverage of defect and split-skin grafting. At the initial post-op period, the patient was on regular follow-up and was compliant with pouch washes

Correspondence: Siddalingeshwar Neeli MD, Jawaharlal Nehru Medical College and KLES Dr Prabhakar Kore Hospital and MRC, Department of Urology, Belagavi, India Phone: +91-831-2473777 E-mail: sineeli@gmail.com ORCID-ID: orcid.org/0000-0001-6565-1443

Received: 30.04 .2020

Accepted: 31.05 .2020

Cite this article as: Neeli S, Nutalpati SH, Sharma M. Gigantic Calculi in Continent Urinary Diversion. J Urol 2020;7(4):325-327

๑Copyright 2020 by the Association of Urological Surgery / Journal of Urological Surgery published by Galenos Publishing House. 
using soda-bicarbonate diligently every week. The mucus secretions gradually reduced and he stopped performing pouch washes and was lost for follow-up.

In September 2018, at age 27 years, he presented with a 7-day history of dull aching right flank and suprapubic pain, fever, vomiting, intermittent hematuria, and pain during selfcatheterization. A non-mobile, hard, and tender mass was felt upon examination in the suprapubic region measuring approximately $8 \times 7 \mathrm{~cm}$ in size. The stoma was catheterizable, functioning, and appeared healthy. His complete hemogram showed neutrophilia and toxic granulocytosis. He had raised serum creatinine $(2.4 \mathrm{mg} / \mathrm{dL})$ and hyperkalemia, and his liver function tests were within the physiologic range. Two radiopaque shadows superimposed on one another in the suprapubic region suggestive of large pouch calculi were revealed by a plain KUB radiograph (Figure 1). Non-contrast enhanced CT scan confirmed the presence of two calculi measuring $8.0 \times 6.3 \times 5.7$ $\mathrm{cm}$ and $8.2 \times 7.5 \times 8.0 \mathrm{~cm}$ in the pouch. The urine culture grew Escherichia coli and Klebsiella pneumoniae.

The patient was adequately hydrated, hyperkalemia was corrected and he was placed on antibiotics. A decision to do an open surgery was taken to remove the large calculi. The continent pouch was identified and carefully dissected from surrounding tissue through an infraumbilical midline transperitoneal incision. A vertical pouchotomy of approximately $7 \mathrm{~cm}$ length

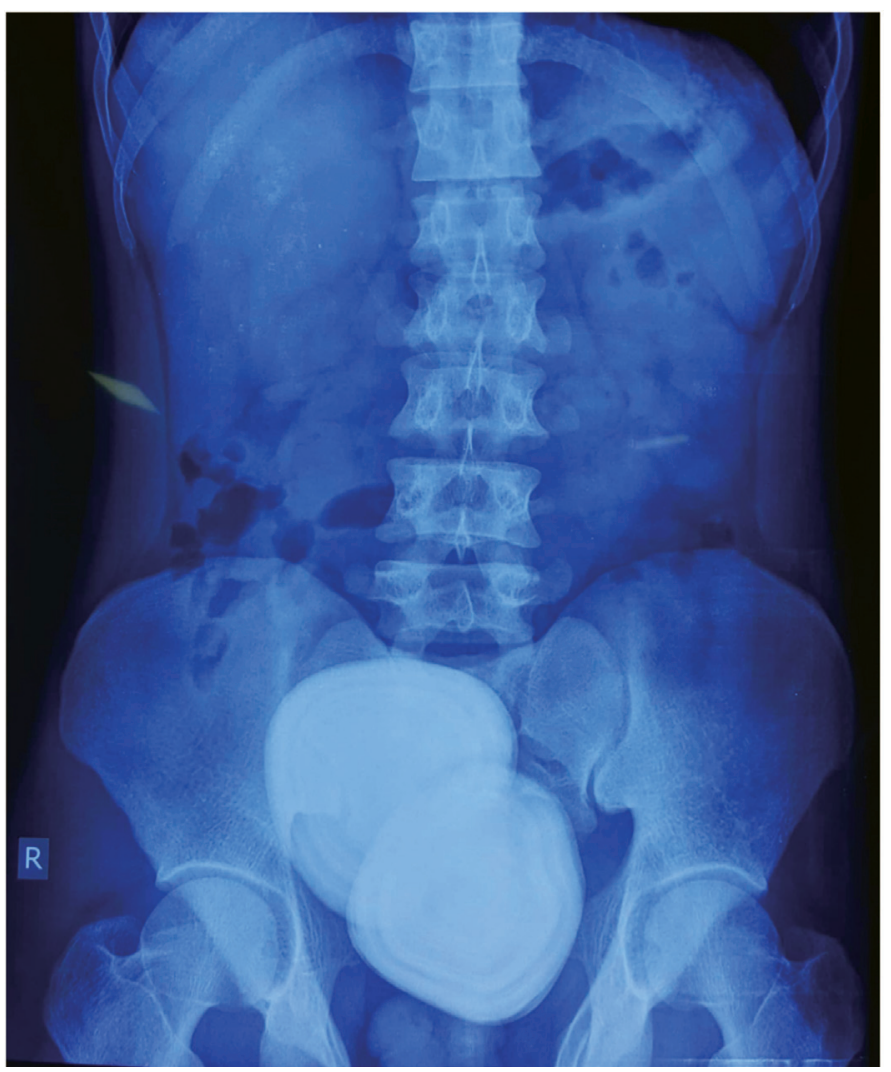

Figure 1. X-ray KUB showing giant pouch calculi was performed over the anterior wall and the two large stones were delivered out (Figure 2). Water-tight closure of pouchotomy was performed in two layers with 3-0 polyglycolic sutures. The pouch was drained with an indwelling catheter for 2 weeks. The postoperative period was uneventful. On infrared spectroscopic analysis, the stone was composed of calcium phosphate, magnesium phosphate, and urate. The patient was reinitiated with self-catheterization and instructed to perform pouch washes regularly to remove the mucus.

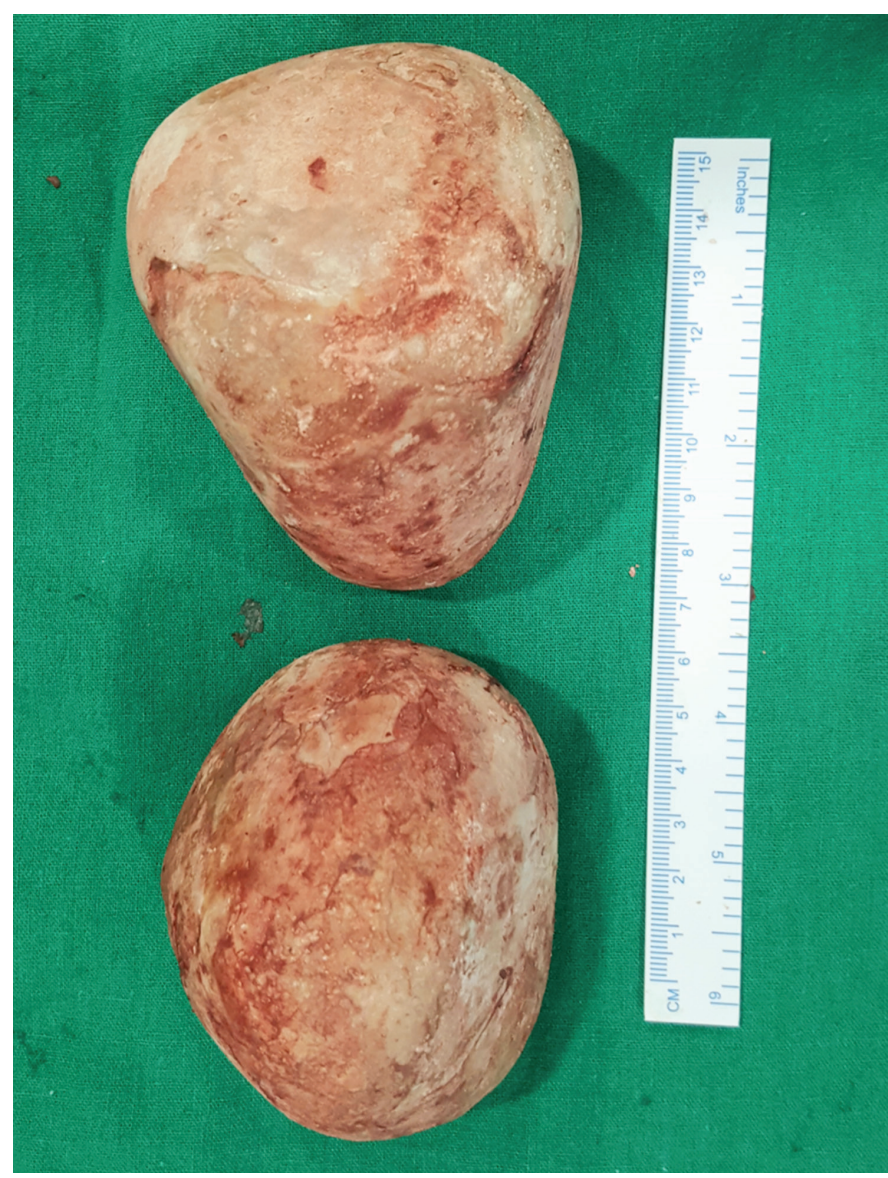

Figure 2. Retrieved pouch calculi

\section{Discussion}

Patients can now achieve and sustain an admirable quality of life due to the progress made in the field of bladder substitution; however, diversion related complications including stone formation remain a concern. Risk factors such as urinary stasis, persistent mucus production by the intestinal segment, recurrent urinary infections, reflux into the upper tracts, and exposed non-absorbable sutures and staples have been implicated for stone formation (9). Irrespective of the type of diversion, the bacterial colonization rate is estimated to range from 14\% to $96 \%$ (10). Though majority of the patients harbor a combination of metabolic or infectious types of calculi, the major 
component of their stone is magnesium ammonium phosphate (struvite). In the literature, it is reported that other stones are composed of calcium oxalate, calcium phosphate, hydrogen urate, and carbonate apatite (11). In spite of the management of urolithiasis in such cases, recurrence is notorious. Cohen et al. (12) reported a recurrence rate of 63\% over a 5-year followup period. Crystalluria and persistent mucus production in the reservoir form nidus for stone recurrence. This highlights the importance of regular and complete drainage of the reservoir along with irrigation in preventing stone recurrence. Hensle et al. (13) reported that irrigation protocol helped in decreasing the incidence of pouch calculi. Additionally, this may benefit by lessening the bacterial count within the reservoir, preventing the development of infective stones (14). There are a plethora of approaches for the management of pouch calculi. Conventionally, an open poucholithotomy is preferred. In patients with low stone burden, various other procedures such as endoscopic and laparoscopic approaches, extracorporeal shock wave Lithotripsy, and percutaneous removal of calculi have been documented (15). In the present case, the patient had two large calculi with superadded active infection. The combined weight of the stones was 1,254 gms, the largest stone burden in continent urinary diversion reported in literature. Open poucholithotomy was preferred in our case, as it seemed to be the best option for managing such large stone burden in the pouch. Stone recurrence within continent diversion maybe prevented by regular and complete drainage of the reservoir alongside irrigation.

\section{Ethics}

Informed Consent: Consent taken from the patient in his vernacular language (kannada).

Peer-review: Externally peer-reviewed.

\section{Authorship Contributions}

Concept: S.N., N.S.H., Design: S.N., N.S.H., Data Collection or Processing: S.N., N.S.H., Analysis or Interpretation: S.N., N.S.H., Literature Search: S.N., M.S., N.S.H., Writing: N.S.H., M.S., S.N.

Conflict of Interest: No conflict of interest was declared by the authors.
Financial Disclosure: The authors declared that this study received no financial support.

\section{References}

1. Costa JA, Kreder K. "Urinary Diversions and Neobladders. Treatment \& Management." (5 Feb. 2019) https://emedicine.medscape.com/ article/451882-overview

2. Beiko DT, Razvi H. Stones in urinary diversions: Update on medical and surgical issues. Curr Opin Urol 2002;12:297-303.

3. Turk TM, Koleski FC, Albala DM. Incidence of urolithiasis in cystectomy patients after intestinal conduit or continent urinary diversion. World J Urol 1999:17:305-307.

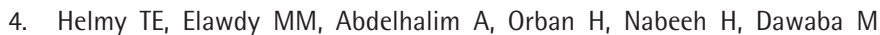
Hafez AT. Treatment of pouch stones after augmentation ileocystoplasty in children: Is it always bothersome? Urology 2015;85:195-198.

5. Szymanski KM, Misseri R, Whittam B, Amstutz S, Kaefer M, Rink RC, Cain MP. Cutting for stone in augmented bladders-what is the risk of recurrence and is it impacted by treatment modality? J Urol 2014;191:1375-1380.

6. Palmer LS, Franco I, Kogan SJ, Reda E, Gill B, Levitt SB. Urolithiasis in children following augmentation cystoplasty. J Urol 1993;150:726-729.

7. Webster C, Bukkapatnam R, Seigne JD, Pow-Sang J, Hoffman M, Helal $M$, Ordorica R, Lockhart JL. Continent colonic urinary reservoir (Florida pouch): long-term surgical complications (greater than 11 years). J Urol 2003;169:174-176.

8. Jesse E, Mahdy A. Surgical Management of large pouch stone in continent urinary diversion. Int Urogynecol J 2018;29:165-166.

9. Okhunov Z, Duty $B$, Smith $A D$, Okeke Z. Management of urolithiasis in patients after urinary diversions. BJU Int 2011;108:330-336.

10. Bishop RF, Smith ED, Gracey M. Bacterial flora of urine from ileal conduit. $J$ Urol 1971;105:452-455

11. Hautmann RE, de Petriconi R, Gottfried HW, Kleinschmidt K, Mattes R, Paiss T. The ileal neobladder: complications and functional results in 363 patients after 11 years of followup. J Urol 1999;161:422-427.

12. Cohen TD, Streem $S B$, Lammert G. Long-term incidence and risks for recurrent stones following contemporary management of upper tract calculi in patients with a urinary diversion. J Urol 1996;155:62-65.

13. Hensle TW, Bingham J, Lam J, Shabsigh A. Preventing reservoir calculi after augmentation cystoplasty and continent urinary diversion: the influence of an irrigation protocol. BJU Int 2004;93:585-587.

14. L'Esperance JO, Sung J, Marguet C, L'Esperance A, Albala DM. The surgical management of stones in patients with urinary diversions. Curr Opin Urol 2004;14:129-134.

15. Benson MC, Olsson CA. Continent urinary diversion. Urol Clin North Am 1999;26:125-147, ix. 